\title{
The Sense of Self-Efficacy of Teachers Working in Special Schools - A Research Communiqué
}

\author{
Beata Maria Nowak \\ Warsaw University of Life Sciences \\ Warsaw, Poland
}

\begin{abstract}
The article presents the results of research on the sense of selfefficacy of teachers working in schools that are an integral part of social rehabilitation and educational centres (for children and young people at risk of social maladjustment and the socially maladjusted) and penal institutions. The main aim of the research was to search for predictors of the sense of self-efficacy of teachers in special schools. The theoretical basis of the research was the theory of social learning by A. Bandura. The research was conducted with the use of a research tool - the "Sense of Efficacy Test" by Chomczyńska-Rubacha and Rubacha. It has been found that the sense of self-efficacy of special school teachers depends on their gender, place of residence, level of education of their mothers and the type of centre in which they are employed. Cluster analysis made it possible to distinguish two independent groups of teachers who achieve high and low scores in terms of the sense of self-efficacy, and to construct a model explaining their assignment to the groups.
\end{abstract}

Keywords: teacher; sense of self-efficacy; special schools; social maladjustment, young people.

\section{Introduction}

One of the underlying assumptions of Bandura's theory of social learning (Bandura, 1977, 1986) is a belief that the primary way in which people acquire skills and behaviours is through observational learning, in which attention, storage, production, memory and motivation processes play a leading role. The focus of attention on a particular object depends on the knowledge and current attitude of an individual. The difficulties that sometimes arise in reproducing (producing) behaviour usually stem from a lack of necessary cognitive, motor and communication skills and a lack of feedback. Bandura analysed human behaviour in the categories of reciprocal determinism, that is in the system of interconnected personal and environmental factors. According to him, external factors influence the course of self-regulatory processes (self-observation, selfevaluation and self-response). The internal standards for assessing the behaviour of a human being stem from from past experiences, and environmental 
influences may change the way the behaviour is evaluated. In addition, Bandura stated that the difficulties of an anxious person or a person deploying stress evasion strategies are the result of their lack of confidence that they can cope with stressful situations on their own. He also proved that self-efficacy is a significant predictor of human behaviour and an essential element of their resources (Bandura, 1993).

The sense of self-efficacy has a strong influence on thinking, emotions and action. It is defined as the individual's conviction of their personal ability to fulfil specific and diverse conditions of a task that lead to the achievement of the intended results (Bussey \& Bandura, 1999, p. 691). The sense of self-efficacy understood in this way is the intermediary between the objectives and the activities leading to their achievement (Pervin \& John, 2002, p. 481). It concerns the conviction that a particular standard can be achieved as a motive to take action.

\section{Literature review}

Numerous theoretical analyses and research results indicate individual conditions for effective action (e.g. Mischel, Schoda \& Peake, 1988; Rubacha, 2000; Oleś, 2003). They all demonstrate that the sense of self-efficacy is created on the basis of personal experience in the area of managing motivational resources (the ability to postpone gratification, self-confidence, developmental motivation, perseverance in action) and in the cognitive and functional area (the ability to convert objectives into an action plan, resistance to frustration and stress, sense of perpetration, inner containment) (Chomczyńska - Rubacha \& Rubacha, 2013).

According to the theory of social learning, improvement of one's own image is possible only when, on the basis of current experience of desired behaviours, a person acquires beliefs about their own abilities and is able to independently produce environmental factors which allow them to act. Then they are able to implement these activities in accordance with the standard of self-improvement shaped in the course of social modelling. In comparison with a reactive environment (perception of the result in terms of correctness), a high sense of self-efficacy results in activity up to a specific behaviour. The lack of reactivity of the environment may lead either to increased social activity of the individual when it is characterized by a high sense of efficacy, or to resignation and withdrawal from the action when the sense of efficacy is low. On the other hand, with low environmental reactivity and low self-efficacy, helplessness and depression appear (Schwarzer \& Fuchs, 1996, as cited in Juczyński, 2000).

The self-efficacy attributed to oneself determines one's persistence in striving for success and determines the strength of engagement, which is a variable of a motivational nature. It refers to the selection of the situations, the establishment of the preferences for the execution of certain actions and the decisions on the manner of action. As Oleś stresses (2003, p. 214), self-efficacy expectations appear even before starting an activity, as opposed to expecting a result, which is located between the activity (behaviour) and its outcome. A high sense of 
efficacy leads to more ambitious choices of actions, more effort put into them and more intellectual achievements. On the other hand, the lack of self-efficacy perceived by an individual causes the reduction of its motivational potential (expectation of a specific result of action) to almost zero level. It is related, among other things, to the phenomenon of professional burnout. Reduced personal involvement means a sense of lack of competence and professional success (Corrigan et al., 1994).

According to the research of Krok and Gerymski (2019), the sense of self-efficacy is also a partial mediator (positive influence) in the relationship between the meaning of life and life satisfaction. Studies carried out by Słupiński and Kałużny (2016) indicate that a sense of self-efficacy and a sense of location of control can have an impact on the choice of style of coping with a difficult situation - the stronger the sense of self-responsibility, the less willingness to react with anxiety and applying failure protection strategies.

In the light of the concept of a sense of professional efficacy derived from social learning theory, it can be assumed that a teacher's sense of professional effectiveness is an individual's belief in being able to influence the change in the student (Ross, Cousins \& Gadalia, 1996) and to plan, organise and carry out activities aimed at achieving educational goals (Skaalvik \& Skaalvik, 2007). In the opinion of Bandura, the sense of self-efficacy may not be related to the sense of professional efficacy. However, the Polish research carried out by Rubacha (2013) showed a high, positive correlation between the generalised sense of selfefficacy and the teachers' sense of pedagogical efficacy. This result is consistent with the results of a study on German and Syrian teachers conducted by R. Schwarzer and S. Hallum (2008).

Research by Salanova, Bakker and Gumbau (2006), in which 258 teachers participated, showed that the sense of self-efficacy and certain principles of work organisation, such as openness of objectives and social support, increase teachers' satisfaction with their work and their internal motivation. Motivation has a regulatory function, and the power of motivation is understood as the degree of its influence on individual choices and aspirations (Chełpa, 2005, p. 89). Motivation can also be defined as reasons important for a given person to induce, direct and sustain desired behaviours. Their strength depends on the hierarchy of objectives and the sense of the value of individual needs (Juchnowicz, 2014, p. 390). On the other hand, motivation to act/work is defined by interrelated, internal and external conditions of people's behaviours in the action/work taken up (Pocztowski, 2007, p. 202). Numerous studies (Klassen \& Chiu 2010, 2011; Baka 2011; Collie et al. 2012; Avanzi et al. 2013; Gilbert et al. 2014; Saricam, Sakiz 2014; Kurowska \& Manys, 2016) showed that higher levels of teachers' sense of self-efficacy is associated with a higher level of commitment, job satisfaction and optimism, and a lower level of occupational burnout. 
Over the past four decades, numerous empirical analyses have been carried out, aimed at searching for the determinants of teachers' sense of self-efficacy in three areas:

- Concerning the teacher - research in this area has shown that the sense of selfefficacy of a teacher increases with:

- the level of their preparation for classes and the resources of substantive, psychological and pedagogical knowledge (e.g. Housego, 1990, 1992; Hoy \& Woolfolk, 1993; Ross, 1994);

- professional experience/years worked in education (e.g. Benz et al., 1992; Gaś, 2002; Kulawska, 2017);

- in-service training (e.g. Coladarci \& Fink, 1995; Coladarci \& Breton, 1997);

- women teachers have a higher sense of self-efficacy than men teachers (e.g. Greenwood, Olejnik \& Parkay, 1990; Raudenbush, Rowan \& Cheong, 1992).

- concerning the student - it became apparent that increasing the teacher's sense of efficacy is significantly impacted by:

- the involvement of students in preparing for classes and their activities (e.g. Huberman, 1992; Ross, Cousins \& Gadalia, 1996);

- the age of students - teachers working with youths have a higher sense of efficacy compared to early school education teachers (e.g. Newmann, Rutter \& Smith, 1989; Raudenbush, Rowan \& Cheong, 1992).

- concerning the institutional working environment of the teacher - The sense of self-efficacy of a teacher increases with:

- their participation in decision-making processes aimed at improving the quality of school work (e.g. Moore \& Esselman, 1992; Raudenbush, Rowan \& Cheong, 1992);

- experiencing a friendly social climate at school (e.g. Hoy, Woolfolk, 1993);

- cooperation between teachers in the field of professional development and solving current didactic and educational problems (e.g. Rosenholtz, 1989; Ross, 1992).

Pupils cultivated by teachers with a high sense of efficacy have a positive attitude towards school (Miskel et al., 1983) and higher educational attainment (Ross, 1992; Muijs \& Rejnolds, 2001; Caprara et al., 2006; Soodak \& Podell, 1996; Leithwood \& Jantzi, 2006). A high sense of self-efficacy of a teacher becomes an impulse for further professional development (Coladarci, 1992), introduction of didactic innovations (Allinder, 1994; Coladarci \& Fink, 1995), creation of supportive professional relations (Morrison \& Walker, 1994) and effective cooperation with students' parents (Hoover-Dempsey, Bassler \& Brissie, 1987).

Therefore, there is no doubt that the school successes of students are primarily determined by the teachers' readiness to react to development changes which take place in all spheres of their work and to create optimal conditions for their comprehensive development. A particularly difficult area of teachers' activity is special education, which requires from them not only substantive knowledge but also in-depth, specialist psychological and pedagogical knowledge, and the 
ability to select the right working methods for the developmental (i.e. physical, mental, intellectual and social) disorders diagnosed in students.

The aim of the research presented in the article is to identify the determinants of the sense of self-efficacy in teachers working in special schools.

\section{Methodology.}

Studies on the self-efficacy of teachers working in special schools were carried out in Poland, in the Mazovia voivodship. This type of school educates children with special educational needs who have developmental disorders and deviations or specific learning difficulties that make it impossible to meet the requirements for implementing the core curriculum.

\subsection{Research Method and Sampling}

The selection of the research sample was based on a purposeful random pattern. First, special schools operating in youth care centers (for youth at risk of social maladjustment) - YCC, youth detention centers (for socially maladjusted youth) - YDC, special education centers (for children who due to disability cannot attend school in the place of residence) - SEC, and in penitentiary institutions (PI) were drawn. The sampling frame was the current list of schools from the Educational Information System.

An integral element of the structure of Polish centers for children and young people at risk of social maladjustment and socially maladjusted are primary or secondary special schools. It is an institution dealing with care, upbringing, education and - depending on the purpose of a given center - rehabilitation, social rehabilitation of children, adolescents and adults with disabilities with disturbed behavior ${ }^{1}$. On the other hand, prisoners $^{2}$ who are under 18 years of age and are obliged to comply with the school obligation and the obligation to study under the act on the education system (obligatory) are qualified in penitentiary institutions; whose individual impact program specifies the need for teaching (at the request of the penitentiary department of the institution); and who have asked to start or continue education in a particular type of school.

Then the sample of teachers was drawn according to a simple random scheme with the same probability of choice. The selection frame was a list of teachers in randomly selected schools. The study included only those respondents who were employed full-time in the randomly selected institution.

1REGULATION OF THE MINISTER OF NATIONAL EDUCATION of 9 August 2017 on the conditions for organizing education, upbringing and care for disabled children and youth, socially maladjusted and at risk of social maladjustment (Journal of Laws of 24 August 2017, item 1578), § 2. 1. (points $5,6,8$ ).

2REGULATION OF THE MINISTER OF JUSTICE of February 13, 2004 on the detailed rules and procedure for conducting teaching in prisons (Journal of Laws No. 37, item 337, as amended) and in accordance with Instruction No. 5 of the General Director of the Prison Service on the detailed mode of organizing teaching in schools and course training in prisons and detention centers of November 25, 2008. 
The sample consisted of 359 teachers, nearly two-thirds were women (65.8\%). The largest group of respondents were teachers employed in the SEC (33.4\%), followed by almost equal representation of teachers working in the YDC (29.2\%) and YCC (29\%). Teachers from the penitentiary institution constituted only $8.4 \%$ of the total number of respondents. The majority of teachers participating in the study were city dwellers ( $80.4 \%$ in total), including the small town (up to 20,000 inhabitants), which was the most represented living environment - $28.7 \%$. Teachers living in the countryside accounted for $19.5 \%$ of the total number of respondents. More than half of the respondents were young $(16.0 \%)$ and middleaged (31-40 years $-38.0 \%$ ) teachers. Older teachers in the $41-50$ age category accounted for $26.0 \%$ of the total number of respondents, and the oldest $(<50$ years) for $20.0 \%$. Almost half of the respondents $(46,5 \%)$ were teachers with relatively low work experience (up to 10 years). Experienced teachers who belonged to the category of 11 to 25 years of professional work constituted $40.3 \%$ of respondents, while the persons with the longest seniority (more than 25 years) represented $13.2 \%$ of the total number of respondents.

Research problems were formulated in the form of the following questions: Is there a relationship between the self-efficacy of teachers and seniority, gender, age and place of residence? Is there a relationship between the self-efficacy of the surveyed teachers and the level of education of their parents? Are there intergroup differences in the sense of self-efficacy of teachers from special schools operating in different types of institutions (YCC, YDC, SEC, PI)?

\subsection{Research Tool}

The study was conducted using a standardized research tool - the Sense of Effectiveness Test (SET) developed by Chomczyńska - Rubacha and Rubacha. It is a self-describing tool, equipped with a four-point scale, containing 17 statements describing various strategies of human action. SET consists of two subscales characterizing cognitive-behavioural and motivational resources. Motivational resources include: developmental motivation and perseverance in action, self-confidence and the ability to postpone gratification. In turn, the cognitive-behavioural resources include: sense of agency, intrinsic steeriness, resistance to frustration and stress, the ability to translate goals into action. The results are calculated by adding up the response weights (according to the key in some items the scale is reversed). The summed values (raw results) are compared to the ten standards included in the textbook.

\section{Research Results}

The results of the research on the sense of self-efficacy of teachers of special schools were discussed in the order corresponding to the research problems included in the description of the research strategy.

\subsection{Teachers' sense of self-efficacy and years worked in education}

The work of teachers teaching in rehabilitation and educational centres for children and youths is multidimensional, challenging and requires continuous professional development, monitoring of learning outcomes and the use of special (including innovative) teaching methods tailored to the individual needs 
and abilities of each student. Taking it into account, it was assumed that the sense of self-efficacy of teachers working in special schools depends on their professional experience and increases with years of work (cognitive, behavioural and motivational resources). However, the analysis of the rho-Spearman correlation did not confirm the existence of such a link. It should be assumed, however, that the research in this area could have been distorted as a result of the phenomenon of professional burnout experienced by the studied teachers. It is all the more likely that teachers from special schools may experience a sense of lack of competence and professional success due to, among other things, the delayed effects of their activities (cf. Corrigan et al., 1994). The desired effects of re-education are usually visible in the long-term perspective in the students of the studied centres, and often a positive change is noticed in them only in adulthood.

\subsection{Teachers' sense of self-efficacy and their sociodemographic characteristics}

The Mann-Whitney $U$ test showed that there was a correlation between gender and the sense of self-efficacy of the studied teachers $(Z=2.06 ; p<0.05)$. Men had much higher scores compared to women (see Table 1 ). In relation to the featured subscales, significant differences were noted only in cognitive and behavioural resources $(Z=3.16 ; p<0.01)$ - also in this case, men obtained higher scores.

Table 1. Average rank values for the sense of self-efficacy according to gender

\begin{tabular}{|l|c|c|}
\hline \multicolumn{1}{|c|}{ gender } & woman & man \\
\hline subscales & 170,89 & 194,62 \\
\hline motivational resources & 176,66 & 183,52 \\
\hline cognitive and behavioural resources & 166,63 & 202,84 \\
\hline
\end{tabular}

The analysis of rho-Spearman's correlation did not confirm the existence of a relationship between the age of the studied teachers and the sense of selfefficacy. Significant correlations were noted in relation to the size of the place of residence. It was found that with the size of the place where the studied teachers live, their cognitive and behavioural resources [significant correlation at the level of 0.01 (bilaterally)] and their self-efficacy [significant correlation at the level of 0.05 (bilaterally)] increase. One of the reasons for this may be the availability of various offers of continuing professional development, including innovative methods and forms of work with students and competence training in the provision of psychological and pedagogical assistance to students. Teachers living in metropolitan areas have easier access to a much wider range of training opportunities than teachers in smaller localities. This is due, among other things, to the fact that various forms of teachers' professional development are usually organized in larger cities.

\subsection{Teachers' sense of self-efficacy and consistency in the educational level of their parents}

The parents of the studied teachers were mostly people with secondary and tertiary education. For most parents, there was consistency between the father 
and the mother in terms of educational attainment (60.4\%). However, empirical verification (Mann-Whitney $U$ test analysis) found that there were no significant differences between teachers whose parents had a consistent or inconsistent level of education. Statistically significant relationships appeared in relation to the level of education of the mothers of the studied teachers. It was found that the teachers' sense of self-efficacy and their cognitive and behavioural resources increase with the level of education of their mothers $[p=0.087$ and $p=0.007$ respectively (significant correlation at 0.01 - bilaterally)]. No significant correlations were observed with respect to the level of fathers' education.

\subsection{Teachers' sense of self-efficacy depending on the type of centre in which the special school operates}

The one-factor analysis of variance confirmed the existence of relations between the analysed variables (in each scale the result was significant at the level of $\mathrm{p}<0.001)$. A thorough analysis using a post-hoc test with Scheffe's amendment has shown that the teachers working in the PI, i.e. in the most isolating institution, obtain higher results in terms of the sense of self-efficacy than the teachers employed in YCCs $(47,68)$, YDCs $(46,05)$, SECs $(44,70)$ and PI $(49,17)$.

The teachers working in the PI also achieved higher results in the cognitive and behavioural resources subscale (average results) in comparison with the teachers employed in other social rehabilitation and educational centres: YCCs $(25,14)$, YDCs $(23,91)$, SECs $(23,95)$ and PI $(26,63)$. Other differences turned out to be statistically insignificant.

As regards the subscale of motivational resources, it turned out that the highest results (average values) were achieved by the teachers employed in YCCs $(22,55)$, YDCs $(22,35)$ and the PI $(22,53)$ - they achieved significantly higher results in comparison with the teachers employed in SECs $(20,75)$.

\subsection{Results of cluster analysis}

It was also considered whether it was possible to create at least two independent groups of teachers on the basis of two sub scales of the sense of self-efficacy (motivational, cognitive and behavioural resources). Therefore, a cluster analysis was carried out using the k-means method. Variables were standardised before the analyses in order to facilitate the interpretation of the results. In the case of 59 teachers, however, there was a problem concerning their unambiguous assignment to one of the groups, which resulted in a reduction in the number of research subjects to 300 . The results of the analysis were the basis for the creation of two independent groups of teachers (the Silhouette measure indicates their good coherence and distinctness):

- group $1(\mathrm{n}=144)$ - teachers achieving high scores $(+)$ in the subscale describing their motivational, cognitive and behavioural resources (Silhouette $=0.68)$;

- group $2(\mathrm{n}=156)$ - teachers with low results (-) in both the analysed subscales (Silhouette $=0.63$ ). 
Then, using a chi-squared analysis, it was examined whether the allocation of teachers to groups depends on gender, age, years worked in education, size of the place of residence, type of centre in which the school operates and level of education of their parents.

There was a correlation between the assignment of teachers to the group and the gender of teachers $\left(\operatorname{chi}^{2}(1)=5.65 ; p<0.05\right)$ - see Table 2 . It has been shown that women are more often qualified to group $2(-)$ than to group $1(+)$. The reverse relationship was observed in men.

Table 2. The relationship between the classification in clusters/groups and the gender of the studied teachers

\begin{tabular}{|c|c|c|c|}
\hline $\begin{array}{c}\text { Number of } \\
\text { cluster/group }\end{array}$ & Cluster/group 1 (+) & Cluster/group 2 (-) & Total \\
\cline { 1 - 3 } Gender & $59.7 \% \mathrm{a}$ & $72.7 \% \mathrm{~b}$ & $66.40 \%$ \\
\hline female & $40.3 \% \mathrm{a}$ & $27.3 \% \mathrm{~b}$ & $33.60 \%$ \\
\hline male & $100.00 \%$ & $100.00 \%$ & $100.00 \%$ \\
\hline Total &
\end{tabular}

* Each letter in the subscript means a subset of the category "observation cluster number", the column proportions of which do not differ significantly from each other at the level of $0.05, \mathrm{~N}=300$.

No significant correlation was found between the assignment of teachers to groups and their age $\left(\mathrm{chi}^{2}(4)=1.68 ; \mathrm{p}>0.05\right)$ and their professional experience $\left(\operatorname{chi}^{2}(6)=5.08 ; p>0.05\right)$. However, significant differences emerged with regard to the place of residence $\left(\mathrm{chi}^{2}(4)=18.90 ; \mathrm{p}<0.01\right)$. The analysis of column comparisons with the Bonferroni amendment showed that respondents from small towns were more often qualified to group 2 (-). In the case of the largest cities, the opposite relationship was observed (see Table 3 ).

Table 3. The relationship between the classification into clusters/groups and the size of the place of residence of the studied teachers

\begin{tabular}{|c|c|c|c|}
\hline Number of cluster/group & Cluster/group 1 & Cluster/group 2 & Total \\
\hline Place of residence & $(+)$ & & lotal \\
\hline village & $18.2 \% \mathrm{a}$ & $21.3 \% \mathrm{a}$ & $19.80 \%$ \\
\hline small town & $20.3 \% \mathrm{a}$ & $36.8 \% \mathrm{~b}$ & $28.90 \%$ \\
\hline medium-sized city & $18.2 \% \mathrm{a}$ & $18.1 \% \mathrm{a}$ & $18.10 \%$ \\
\hline large city & $11.2 \% \mathrm{a}$ & $10.3 \% \mathrm{a}$ & $10.70 \%$ \\
\hline city $>500,000$ inhabitants & $32.2 \% \mathrm{a}$ & $13.5 \% \mathrm{~b}$ & $22.50 \%$ \\
\hline Total & $100.00 \%$ & $100.00 \%$ & $\begin{array}{c}100.00 \\
\%\end{array}$ \\
\hline
\end{tabular}

* Each letter in the subscript means a subset of the category "observation cluster number", the column proportions of which do not differ significantly from each other at the level of $0.05, \mathrm{~N}=300$. 
Significant differences were also found in relation to the place of employment of the studied teachers $\left(\operatorname{chi}^{2}(3)=18.68 ; \mathrm{p}<0.001\right)$ - see Table 4. It was shown that teachers working in YCCs were significantly more often qualified to group $1(+)$, while in the case of teachers working in SECs, the relationship turned out to be reversed - they were more often assigned to group $2(-)$. In the case of teachers teaching in YDCs and the PI, no significant dependence was observed in the analysed scope.

Table 4. The relationship between the qualification to clusters/groups and the place of employment of the studied teachers

\begin{tabular}{|c|c|c|c|}
\hline \multicolumn{1}{|c|}{$\begin{array}{c}\text { Number of cluster/group } \\
\text { Centres where teachers are } \\
\text { employed }\end{array}$} & $\begin{array}{c}\text { Cluster/group 1 } \\
(+)\end{array}$ & $\begin{array}{c}\text { Cluster/group 2 } \\
(-)\end{array}$ & Total \\
\hline youth care centre & $39.6 \% \mathrm{a}$ & $19.9 \% \mathrm{~b}$ & $29.30 \%$ \\
\hline youth detention centre & $29.2 \% \mathrm{a}$ & $30.8 \% \mathrm{a}$ & $30.00 \%$ \\
\hline special education centre & $22.9 \% \mathrm{a}$ & $42.3 \% \mathrm{~b}$ & $33.00 \%$ \\
\hline penal institution & $8.3 \% \mathrm{a}$ & $7.1 \% \mathrm{a}$ & $7.70 \%$ \\
\hline \multicolumn{1}{|c|}{ Total } & $100.00 \%$ & $100.00 \%$ & $\begin{array}{c}100.00 \\
\%\end{array}$ \\
\hline
\end{tabular}

* Each letter in the subscript means a subset of the category "cluster/group number", the column proportions of which do not differ significantly from each other at the level of $0.05, \mathrm{~N}=300$.

There was also no correlation between the assignment of teachers to groups and the level of education of the mothers $\left(\operatorname{chi}^{2}(2)=4.13 ; \mathrm{p}>0.05\right)$ and the fathers $\left(\operatorname{chi}^{2}(2)=0.26 ; \mathrm{p}>0.05\right)$ and the consistency of the educational level of the parents $\left(\operatorname{chi}^{2}(1)=0.29 ; \mathrm{p}>0.05\right)$.

In the next stage of the study, it was examined using logistic regression analysis, whether it was possible to ascribe the qualifications of the respondents to separate groups on the basis of gender, size of the place of residence and the centre where the studied teachers are employed. Detailed results have been presented in Table 5. A model well matched to the data was obtained $\left(\mathrm{chi}^{2}(5)=\right.$ 29.38; $\mathrm{p}<0.001)$ that explains the inclusion of the teachers into the separated groups in $13 \%$.

Table 5. The significance of predictors explaining classification in clusters

\begin{tabular}{|c|c|c|c|c|c|}
\hline Predictors & B & SE & Wald & Significance & $\operatorname{Exp(B)}$ \\
\hline gender & -0.444 & 0.276 & 2.585 & 0.108 & 0.641 \\
\hline $\begin{array}{c}\text { place of } \\
\text { residence }\end{array}$ & -0.241 & 0.088 & 7.432 & $\mathbf{0 . 0 0 6}$ & 0.786 \\
\hline YCC & -1.033 & 0.328 & 9.922 & $\mathbf{0 . 0 0 2}$ & 0.356 \\
\hline SEC & -0.445 & 0.308 & 2.09 & 0.148 & 0.641 \\
\hline constant & 1.840 & 0.478 & 14.829 & 0.000 & 6.299 \\
\hline
\end{tabular}


A good match between the model and the data was also confirmed using the Hosmer and Lemeshov test $\left(\operatorname{chi}^{2}(8)=4.46 ; \mathrm{p}>0.05\right)$. A high convergence of the observed data and model predictions was found (62\%). The model explains the qualification to group $2(65 \%)$ slightly more accurately than to group $1(58 \%)$. It was found that with the size of the place of residence and employment in YCCs, the chance of the studied teacher to be qualified into group $1(+)$ increases.

\section{Conclusion}

The results of the study constitute the basis for the following conclusions: (1) the sense of self-efficacy of teachers in special schools does not depend on the number of years they have worked in education and is not connected with the sense of professional efficacy; (2) male teachers working in special schools have a higher sense of self-efficacy than female teachers; (3) teachers living in small towns and rural areas have a lower sense of self-efficacy and scarcer cognitive and behavioural resources; (4) the sense of self-efficacy builds upon an individual's personal experience of disposing of motivational resources; (5) teachers whose mothers have a higher level of education are characterized by a high sense of self-efficacy, as well as higher cognitive and behavioural resources; (6) teachers in prison schools have a significantly higher sense of self-efficacy and cognitive and behavioural resources; (7) high self-efficacy is characteristic for teachers of special schools operating in centres located in large cities and teachers teaching in YCCs. To sum up, the perception of oneself as a teacher and one's own efficacy is the result of personal life and professional experience, observation and reflection on the conducted didactic and upbringing activity. The results of the presented research encourage to undertake activities aimed at reinforcing the sense of self-efficacy, including motivational, and cognitive and behavioral resources of teachers of special schools run by YDCs and SECs. Female teachers and, regardless of gender, teachers living in small towns and rural areas also need to be supported in this regard. The territorial scope of the study limits the generalization of results to the countries of Central and Eastern Europe due to their similar cultural and historical conditions. Hence, comparative research using the presented research project in countries with different cultures or other educational systems would be justified.

\section{References}

Allinder, R. M. (1994). The relationship between efficacy and the instructional practices of special education teachers and consultants. Teacher Education and Special Education, 1 (2), 86-95. https:/ / doi.org/10.1177/088840649401700203

Avanzi, L., Miglioretti, M., Velasco, V., Balducci, C., Vecchi, L., Fraccaroli, F., \& Skaalvik, E. M. (2013). Cross-Validation of the Norwegian Teacher's Self-Efficacy Scale (NTSES). Teaching and Teacher Education, 31, 69-78.

Baka, Ł. (2011). Baka Ł. (2011). Konflikt między pracą i rodziną a wypalenie zawodowe. Pośrednicząca rola zasobów osobowych [The conflict between work and family and occupational burnout. The mediating role of personal resources]. Psychologia Społeczna, 64(19), 367-374.

Bandura, A. (1977). Self-efficacy: Toward a unifying theory of behavioural change. Psychological Review, 84(2), 191-215. http://dx.doi.org/10.1037/0033295X.84.2.191 
Bandura, A. (1986). Social foundations of thought and action: A social cognitive theory. Englewood Cliffs: Prentice-Hall.

Bandura, A. (1993). Perceived self-efficacy in cognitive development and functioning. Educational Psychologist, 28(2), 117-148. http://dx.doi.org/10.1207/s15326985ep2802_3

Benz, C., Bradley, L., Alderman, M., \& Flowers, M. (1992). Personal teaching efficacy: Developmental relationships in education. Journal of Educational Research, 85(5), 274-286. https:// doi.org/10.1080/00220671.1992.9941127

Bussey, K., \& Bandura, A. (1999). Social cognitive theory of gender development and differentiation. Psychological Review, 106(4), 676-713. http://dx.doi.org/10.1037/0033-295X.106.4.676

Caprara, G. V., Barbaranelli, C., Steca, P., \& Malone, P. S. (2006). Teachers' self-efficacy beliefs as determinants of job satisfaction and students' academic achievement: A study at the school level. Journal of School Psychology, 44(6), 473-490. http://dx.doi.org/10.1016/j.jsp.2006.09.001

Chełpa, S. (2005). Term: Motivation. In: T. Listwan, Human resources management dictionary (p. 89). C.CH. Beck Publishing House.

Chomczyńska-Rubacha, M., \& Rubacha, K. (2013). Sense of Efficacy Test. Torun: The Nicolaus Copernicus University Publishing House. http://dx.doi.org/10.12775/PBE.2013.007

Coladarci, T. (1992). Teachers' sense of efficacy and commitment to teaching. Journal of $\begin{array}{llll}\text { Experimental 6ducation, 323-337. } & \text { 60(4), }\end{array}$ http://dx.doi.org/10.1080/00220973.1992.9943869

Coladarci, T., Breton, B. (1997). Teacher efficacy, Supervision, and the Special Education Resource-Room Teacher. Journal of Educational Research, 90(4), 230-398. http://doi.org/10.1080/00220671.1997.10544577

Coladarci, T., \& Fink, D. R. (1995). Correlations among measures of teacher efficacy: Are they measuring the same thing? Paper presented at the 1995 meeting of the American Educational Research Association, San Francisco.

Collie, R. J., Shapka, J. D., \& Perry, N. E. (2012). School Climate and Social-Emotional Learning: Predicting Teacher Stress, Job Satisfaction, and Teaching Efficacy. Journal of Educational Psychology, 104, 1189-1204. http://dx.doi.org/10.1037/a0029356

Corrigan, P. W., Holmes, P. E., Luchins, D., Buican, B., Basit, A., \& Parks, J. J. (1994). Staff burnout in psychiatric hospital: A cross-lagged panel design. Journal of Organizational Behavior, 15(1), 65-74. https://doi.org/10.1002/job.4030150107

Gaś, Z. (2002). Poczucie skuteczności profesjonalnej nauczycieli o różnym stażu w zawodzie [The sense of professional efficacy of teachers with different professional experience]. Psychological Review, 45(1), 57-74.

Gilbert, R. B., Adesope, O. O., \& Schroeder, N. L. (2014). Efficacy Beliefs, Job Satisfaction, Stress and Their Influence on the Occupational Commitment of English-Medium Content Teachers in the Dominican Republic. Educational Psychology, 34, 876-899. https://doi.org/10.1080/01443410.2013.814193

Greenwood, G., Olejnik, S., \& Parkay, F. (1990). Relationships between four teacher efficacy belief patterns and selected teacher characteristics. Journal of Research and Development Education, 23(2), 102-107. https://doi.org/10.1016/S0742051X(96)00045-5

Gurian, M., \& Annis, B. (2008). Leadership and the sexes. San Francisco: Jossey-Bass.

Hoover-Dempsey, K., Bassler, O., \& Brissie, J. (1987). Parent involvement: Contributions of teacher efficacy, school socioeconomic status, and other school characteristics. American Educational Research Journal, 24(3), 417-435. http://dx.doi.org/10.3102/00028312024003417 
Housego, B. (1990). A comparative study of student teachers' feeling of preparedness to teach. Alberta Journal of Educational Research, 30(3), 223-240.

Housego, B. (1992). Monitoring student teachers' feeling of preparadness to teach, personal teaching efficacy, and teaching efficacy in a new secondary teacher education program. Alberta Journal of Educational Research, 38(1), 49-64.

Hoy, W. K., \& Woolfolk, A. E. (1993). Teachers' sense of efficacy and the organizational health of schools. The Elementary School Journal, 93(4), 355-372. http://dx.doi.org/10.1086/461729

Huberman, M. (1992). Teacher development and instructional mastery. In: A. Hargreaves, M. Fullan (ed.), Understanding teacher development (pp. 122-142). New York: Teachers College Press.

Juczyński, Z. (2000). Poczucie własnej skuteczności - teoria i pomiar [Sense of selfefficacy - theory and measurement]. Acta Universitatis Lodziensis Folia Psychologica, 4, 11-24.

Juchnowicz, M. (2014). Human capital management. Processes - tools - applications. Warsaw: Polish Economic Publishing House.

Klassen, R., \& Chiu, M. M. (2010). Effects on Teachers' Self-Efficacy and Job Satisfaction: Teacher Gender, Years of Experience, and Job Stress. Journal of Educational Psychology, 10 (3), 741-756. http://dx.doi.org/10.1037/a0019237

Klassen, R., \& Chiu, M. M. (2011). The Occupational Commitment and Intention to Quit of Practicing and Pre-Service Teachers: Influence of Self-Efficacy, Job Stress, and Teaching Context. Contemporary Educational Psychology, 36, 114-129. http://dx.doi.org/10.1016/j.cedpsych.2011.01.002

Krok, D., \& Gerymski, R. (2019). Self-efficacy as a mediator of the relationship between meaning in life and subjective well-being in cardiac patients. Current Issues in Personality Psychology, 7(3), 242-251. https://doi.org/10.5114/cipp.2019.89168

Kulawska, E. (2017). Poczucie własnej skuteczności nauczycieli edukacji wczesnoszkolnej [Sense of self-efficacy of early school education teachers] Pedagogical Forum, 2, 237-251.

Kunowska, K., \& Manys, K. (2016). Poczucie własnej skuteczności a umiejscowienie kontroli zdrowia $\mathrm{w}$ grupie osób $\mathrm{z}$ rozpoznaniem nadciśnienia tętniczego [Selfefficacy and location of health control in a group of people diagnosed with hypertension]. PRACA ORYGINALNA, 3, 239-245.

Leithwood, K., \& Jantzi, D. (2006). Transformational school leadership for large-scale reform: Effects on students, teachers, and their classroom practices. School Effectiveness and School Improvement, 17(2), 201-227. https://doi.org/10.1080/09243450600565829

Mischel, W., Schoda, Y., \& Peake, P. (1988). The Nature Adolescent Competences Predicted by Preschool Delay of Gratification, Journal of Personality and Social Psychology, 54(4), 687-696. http://dx.doi.org/10.1037/0022-3514.54.4.687

Miskel, C., McDonald, D., \& Bloom, S. (1983). Structural and expectancy linkages within schools and organizational effectiveness. Educational Administration Quarterly, 19(1), 49-82. https://doi.org/10.1177/0013161X83019001004

Moore, W., \& Esselman, M. (1992). Teacher efficacy, empowerment, and a focussed instructional climate: Does student achievement benefit? Paper presented at the annual meeting of the American Educational Research Association, San Francisco.

Morrison, G. M., Walker, D., Wakefield, P., \& Solberg, S. (1994). Teacher preferences for collaborative relationships: Relationship to efficacy for teaching in preventionrelated domains. Psychology in the Schools, 31(3), 221-231. http://dx.doi.org/10.1002/1520-6807(199407)31:3<221::AID-

PITS2310310307>3.0.CO;2-E 
Muijs, R. D., \& Reynolds, D. (2001). Teachers' beliefs and behaviors: What really matters. Journal of Classroom Interaction, 37(2), 3-15.

Neumann, F., Rutter, R., \& Smith, M. (1989). Organizational Factors that affect school sense of efficacy, community, and expectations. Sociology of Education, 62(4), 221238. http://dx.doi.org/10.2307/2112828

Oleś, P. (2003).Introduction to personality psychology.Warsaw: Scholar.

Pervin, L. A., \& John, O. P. (2002). Osobowość. Teoria i badania [Personality. Theory and research, Rev. 8]. Cracow: UJ.

Pocztowski, A. (2007). Human resources management. Strategies - processes - methods. Warsaw: Polish Economic Publishing House.

Raudenbush, S., Rowan, B., \& Cheong, Y. (1993). Higher order instructional goals in secondary schools: Class, teacher, and school influences. American Educational Research Journal, 30(3), 523-553. https:// doi.org/10.3102/00028312030003523

Rosenholtz, S. (1989). Teachers' workplace: The social organization of schools. New York: Longman.

Ross, J. A. (1992). Teacher efficacy and the effect of coaching on student achievement. Canadian Journal of Education, 17(1), 51-65. http:// dx.doi.org/10.2307/1495395

Ross, J. A. (1994). The impact of an in-service to promote cooperative learning on the stability of teacher efficacy. Teaching and Teacher Education, 10(4), 381-394. http://dx.doi.org/10.1016/0742-051X(94)90020-5

Ross, J. A., Cousins, J. B., \& Gadalia, T. (1996). Within-teacher predictors of teacher efficacy. Teaching and Teacher Education, 12(4), 385-400.

Rubacha, K. (2000). Pełnienie roli nauczyciela a realizacja zadań rozwojowych w okresie wczesnej dorosłości [Playing the role of a teacher and carrying out development tasks in early adulthood]. Torun: The Nicolaus Copernicus University Publishing House.

Rubacha, K. (2013). Uogólnione poczucie skuteczności apoczucie skuteczności wychowawczej rodziców i nauczycieli. Hipoteza sytuacyjnej zmienności [Generalised sense of efficacy and the sense of upbringing efficacy of parents and teachers. Hypothesis of situational variability]. Polish Journal of Educational Studies, 25, 75-83.

Salanova, M., Bakker, A., \& Gumbau, S.L. (2006). Flow at work: Evidence for an Upward Spiral of Personal and Organizational Resources, Journal of Happiness Studies, 7(1), 1-22, February. http://dx.doi.org/10.1007/s10902-005-8854-8

Saricam, H., \& Sakiz H. (2014). Burnout and Teachers Self-Efficacy among Teachers Working in Special Education in Turkey. Educational Studies, 40, 423-437. http://dx.doi.org/10.1080/03055698.2014.930340

Schwarzer, R., \& Hallum S. (2008). Perceived Teacher Self-Efficacy as a Predictor of Job Stress and Burnout: Mediation Analysis. Applied Psychology, 57(1), 152-171. http://doi.org/10.1111/j.1464-0597.2008.00359

Skaalvik, E. M., \& Skaalvik, S. (2007). Dimensions of Teacher Self-Efficacy and Relations With Strain Factors, Perceived Collective Teacher Efficacy, and Teacher Burnout. Journal of Educational Psychology, 99(3), 611-625. http:// dx.doi.org/10.1037/00220663.99.3.611

Soodak, L. C., \& Podell, D. M. (1996). Teacher efficacy: Toward the understanding of a multi-faceted construct. Teaching and Teacher Education, 12(4), 401-411. http:/ / dx.doi.org/10.1016/0742-051X(95)00047-N

Supiński, J., \& Kałużny, K. (2016). Poczucie własnej skuteczności oraz umiejscowienia kontroli a styl radzenia sobie ze stresem u lekkoatletów i studentów wychowania fizycznego [Self-efficacy and control placement and the style of coping with stress in athletes and physical education students] (Scientific dissertation, The University of Physical Education, Wrocław). 